\title{
Examining the Application of Grammatical Metaphors in Academic Writing
}

\author{
Ying Zhang ${ }^{1}$ \\ ${ }^{1}$ English Department, North China Electric Power University, Baoding, Hebei Province, China \\ Correspondence: Ying Zhang, English Department, North China Electric Power University, Baoding, Hebei \\ Province, China.
}

\author{
Received: April 16, 2018 Accepted: May 14, 2018 Online Published: May 24, 2018 \\ doi:10.5539/ells.v8n2p108 URL: https://doi.org/10.5539/ells.v8n2p108
}

\begin{abstract}
English academic writing is a challenging task for Chinese EFL learners. For graduate students, they need systematic and explicit guidance to improve their academic writing competence. Grammatical metaphors are important resources for constructing academic discourse, and nominalization in ideational metaphors is regarded as the most powerful tool for achieving formality, objectivity, lexical density and text cohesion typical of academic papers. This article focuses on the role of grammatical metaphors in the production of quality academic written texts. It analyzes the function of grammatical metaphors in academic register and the application of these grammatical metaphors in creating academic meanings. The paper also provides some pedagogical implications for academic writing instruction for advanced EFL learners.
\end{abstract}

Keywords: academic writing, grammatical metaphor, nominalization

\section{Introduction}

With the fast development of international exchanges for academic purposes, English is viewed as one of the most important academic languages in the world. Accordingly, the requirements for graduate students' academic writing and communication abilities in English are also improved. However, academic discourse is quite different from the language used for daily social interactions. In general, academic written discourse is a formal style of communication. Academic language manifests a high level of lexical density and authority in attitude and tone, and the arguments take place within clauses but not between clauses (Halliday \& Matthiessen, 2004). The development of English academic writing abilities is a transformation process from an informal spoken form of expressions to a formal written form of expressions. The language used in academic writing context needs to be reconstructed to convey the dynamic sequence of events through static and synoptic entities that can be organized, compared and evaluated in a systematic way (Martin, 1993; Schleppegrell, 2004). However, this shifting process may even make the L1 novice writers have trouble. For most EFL graduate students in China, they have not received specific writing instruction for academic purposes before studying for their master degree. Thus, there is an urgent need for them to learn to know the particular characteristics of the style of language used in academic writing to improve their academic writing competence.

Systemic Functional Linguistics (SFL) views language as a choice of making meanings and describes grammar as functional for communicative purposes (Halliday \& Matthiessen, 1999). SFL attaches great importance to language users' development of increasingly sophisticated communication abilities. The main feature of this developmental process is that language users gradually grasp the meanings between different levels, that is, expressing more than one meaning at a time. The meaning potentials of the language are no longer just congruent and specific expressions (Halliday, 1993). The incongruent and abstract use of language forms are mainly realized through grammatical metaphor. For example, a process meaning is conveyed through a nominal group rather than a verbal group, and the logical meaning is embodied by a verbal group or a prepositional phrase rather than a conjunction. This offers language users rich resources for constructing meanings in written language. Halliday\& Martin (1993) put forward that "The birth of science is realized semiotically by the birth of grammatical metaphor" (p. 15). Ravelli (2003) also believes that grammatical metaphors are the core of written discourse, especially the science and academic discourse. This suggests that the employment of grammatically metaphorical expressions is one of the most important features in academic papers. Grammatical metaphor enables language users to express relationships among actions, events and circumstances in an impersonal, 
objective, formal, and abstract manner which is in line with the styles of language required in academic context.

Grammatical metaphor, identified as a key feature of academic genre, is a necessary and important tool for the development of high-level language competence, which has become a hot research topic under the framework of SFL. A number of studies on L1 learners were conducted (e.g. Christie, 2002; Christie \& Derewianka, 2008; Derewianka, 2003; Ravelli, 2003), and some studies were conducted to explore ESL learners' use of grammatical metaphors (e.g. Chen \& Foley, 2004; Liardet, 2013; 2015; Schleppegrell, 2004). This paper aims to analyze and explore the roles of grammatical metaphor in the production of quality academic papers to gain a deeper insight into the potential difficulties of Chinese advanced EFL learners' use of grammatical metaphor in writing research papers. It also discusses pedagogical implications for the teaching practice of English academic writing.

\section{Register of English Academic Writing}

\subsection{Overall Stylistic Features of Academic Writing}

The purpose of academic writing is to inform rather than entertain. Its style is quite different from that of an English composition or that of an oral presentation. In general, academic writing is in an objective, formal, concise and complex style. As a form of scientific research, academic papers are targeted at readers or scholars of specific disciplines who are more interested in research findings, thus all the findings are expected to be reported in an objective or impersonal way which requires little of one's personal emotions or opinions. Words and phrases are more formal. For example, standard and full forms of expressions and single-verbs are preferred. In addition, academic papers contain more grammatically complex sentences. Usually they have more subordinate clauses, more long sequences of prepositional phrases and more attributive adjectives. All the ideas must be presented in a concise way, which means you have to avoid repetition and reduce the unnecessary words to find the most direct way to express precisely what you want it to mean.

\subsection{Grammatical Features of Academic Register}

According to SFL, register is defined as "the clustering of semantic features according to situation type" (Halliday, 1978, p.68). That means register refers to the use of language varieties in different situations. There are three main dimensions of varieties that characterize a certain register: field, tenor and mode. Field is related to what is being talked about; tenor deals with people involved in communication; and mode is realized though different expectations for how particular types of text should be organized, for example, written or spoken.

In terms of field, the academic writing requires a higher level of lexical density. There are more content words employed in a clause in academic writing. For example:

(1) Obviously the university is frightened of students' union reaction to its move to impose proper behaviour on unions.

(2) Obviously the university is frightened how the students union will react if it tries to make them behave properly.

Sentence (1) is more lexically dense to convey the information in a formal way than sentence (2) which appears less formal. This may due to the fact that a great amount of information needs to be packed in a clause in academic writing.

Considering the aspect of tenor, the relationship between participants in the academic communication context is that the writer is the provider of information and the readers are the recipients of information. Thus, the most typical mood employed in academic papers is the declarative mood. Besides, the writer has to convey the information to readers in an authoritative and impersonal manner (Schleppegrell, 2004). To obtain this effect, extensive use of passive voice is found in academic texts which helps the writer remain objective and direct readers' attention to the information itself.

From the perspective of SFL, mode is related to the organization of texts. In academic contexts, dense and complex information has to be organized in a logical and coherent way. According to Schleppegrell (2004), the information in academic context is organized in a hierarchical way by using the devices of embedded clauses and nominalization. Embedded clauses are a useful device of condensing information and avoiding unnecessary repetition through arranging the relationship between different clauses in academic texts. Another feature with the academic text is that it employs nouns more often than verbs, and this is realized by the process of nominalization. Nominalization transfers actions and processes into things and events to express meanings in an objective and impersonal tone.

\section{Grammatical Metaphor}

Grammatical metaphor is the core of systemic functional linguistics and a key factor in one's literacy 
development. According to systemic functional linguists, meanings that construed in a different way from the normal and ordinary pattern by means of a particular grammatical structure are called grammatical metaphor. This incongruent use of language between the semantic layer and lexicogrammatical layer plays a significant role in social communications. Grammatical metaphor can be further divided into two basic types: ideational metaphor and interpersonal metaphor (Halliday, 1985).

\subsection{Ideational Metaphor}

Ideational metaphor is mainly realized through transitivity process, which involves the change of transitivity functions, such as participant, process, circumstance and so on. When people communicate to convey different meanings, they usually consider their use of language from the following three aspects: 1) to choose from six transitivity processes: material process, mental process, relational process, verbal process, behavioral process and existing process; 2) to select participants of the process, such as actor, sayer, phenomenon, etc.; 3) to choose forms of language to perform the function in a certain context (Halliday, 1985). Obviously, ideational metafunction belongs to the semantic system while the transitivity process belongs to the grammatical system. When the selected form of language encodes the meaning in the most usual way it expresses, such as using verbs to describe actions, adverbial groups or prepositional phrases to express circumstance, the language form is viewed as congruent, otherwise the language form is as incongruent. The incongruent way of encoding meanings is realized through the grammatical metaphor. The grammatical metaphor of transitivity process is primarily presented as the process of nominalization. For example:

(1) The final section is to discuss the results obtained and state any conclusions which may be drawn from those results.

(2) The final section is a discussion of the results obtained and a statement of any conclusions which may be drawn from those results.

As shown in the examples, the main transitivity process in sentence (1) is a verbal process and in sentence (2) is a material process. The participant has been transferred from the sayer in sentence (1) to the actor in sentence (2). The functions of each element in the clause are also changed in line with the change of the transitivity process. And this change in semantics is realized though the change of language forms, that is, from verbal groups to nominal groups, the process of nominalization.

\subsection{Interpersonal Metaphor}

Interpersonal function in communication is realized through mood and modality in the grammatical system, thus interpersonal metaphor can be further divided into two types: mood metaphors and modality metaphors. Mood metaphor is related to speech function, and the semantic function of discourse is achieved through an incongruent mood choice in grammar. Mood metaphors are used more frequently in spoken texts. In academic texts, the most frequently used mood is declarative mood, and the mood metaphors are seldomly used. Modality indicates language user's attitude or opinion towards the truth of a proposition. It ranges from the area between positive and negative polarity (Halliday, 1985). Modality is expressed congruently through modal operators and modal adjuncts. Modality metaphors are used when the modality is realized through other grammatical forms, such as nouns, prepositional phrases, projecting clause complexes. For example:

(1) He will probably remember the teacher.

(2) I believe that he will remember the teacher.

(3) It's likely that he will remember the teacher.

Sentence (1), (2) and (3) focus on the attitude towards the same proposition "he will remember the teacher", but this attitude is expressed in an implicit way through the modal adjunct "probably"in sentence (1). While in sentence (2), this attitude is expressed explicitly in an subjective way though the projecting clause complex "I believe that...". In sentence (3), the source of this attitude is hidden behind, and the attitude is expressed explicitly in an objective way through the projecting clause complex "It's likely that...". And in sentence (2) and (3), this attitude or opinion is realized through an incongruent way rather than through the use of modal operators or modal adjuncts, in which modality metaphors are employed.

\section{The Role of Grammatical Metaphor in Academic Writing}

From the perspective of SFL, the construct of nominalization is one pattern of a larger construct, grammatical metaphor (Halliday \& Matthiessen, 1999). As a typical feature of grammatical metaphor in academic written texts, nominalization is a process in which the grammatical categories are shifted to nouns or nominal groups from various lexicogrammatical forms. Nominalization involves changes in functions but not in semantics. For 
example:

(1) The findings interested many scientists.

(2) Many scientists' interest in the findings...

The two sentences express the same meaning, but with different functions of the element in the clause. In sentence (1), the mental process is realized by a verbal group "interested", while in sentence (2), this has changed to a nominal group "interest". Although the wordings and functions of these wordings in communication are different, the meanings remain the same. The major functions of nominalization in academic written texts are as follows.

First, nominalization makes the academic written texts more formal. In formal texts, such as scientific and technological texts, the phenomena to be revealed, the truth to be clarified, and the experiences of the world to be presented are usually abstract concepts. They provide people with the findings of the scientific study in which the nominalization is generally used. The nominalization allows for the condensation of information through actions, events and circumstances in an abstract and incongruent way. The use of nominal groups in clauses produces higher lexical density and effectively increases the amount of information conveyed to readers. Thus, readers can process more information in each clause (Schleppegrell, 2004). For examples (Burns, 2001):

(1)Furthermore, as students rely on scripted spoken texts, they become less able to interact outside the classroom where people in the world converse without a script.

(2)Furthermore, reliance on scripted spoken texts retards students' ability to interact in the unscripted world of conversation outside the classroom.

The meanings in sentence (1) and (2) are basically the same, but the functions are different. Sentence (1) is an actual description of the concrete happenings, while sentence (2) condenses all the information into one action in an abstract way. In terms of lexicogrammar, sentence (1) shows a low lexical density of about three lexical items per clause and a high grammatical intricacy of three clauses; sentence (2)'s lexical density is seven per clause and it shows a low grammatical intricacy of one clause. In addition, sentence (1) puts focus on "students", concrete people or things, while sentence (2) emphasizes the impersonal entities of "students' abilities" and the explicit analysis of the factors affecting students' abilities.

The example shows that the metaphorical use of nominalization plays a significant role to abstract and generalize the information in academic written texts to make it more formal and technical. High lexical density and low grammatical intricacy help convey more information to readers with a focus on the entities which serves as the departure for further development of the text.

Second, nominalization functions as a cohesive device in academic written texts, which is realized through the structure of theme-rheme. The nominalization of lexicogrammatical constituents, such as verbal groups, functions as the theme in a clause that gives a reference to previous texts. Meanwhile, the nominalization can also function as the rheme of a clause to prepare for the new information coming in the next clause. Thus, the cohesive connection of meanings exists within a discourse, which is realized through nominalization. For example:

(1) For decades, each new advance in weaponry was deployed by one side for the purpose of inspiring fear in the other. But each such deployment led to an effort by the other to leapfrog the first one.

(2) People are talking about whether this ancient temple should be repaired. This discussion has attracted more and more attention.

In sentence (1), the cohesion of the discourse is realized through the word "deployment" referring back to the verb "deploy". In the second clause, "deployment" functions as the theme by nominalizing the verb "deploy". This nominalization functions as a lexical device to promote cohesive organization of the written discourse. In sentence (2), the cohesion of the discourse is made through the connection between the two expressions "talk about" and "discussion". "Discussion" functions as the theme of the second clause by nominalizing the verb "discuss" which is a synonym of the verbal group "talk about". Thus, "discussion" is used to refer back to the former information through "talk about" in the rheme of the first clause.

To summarize, nominalization functions as an important device to maintain textual cohesion in academic writing.

Third, nominalization in ideational metaphor is a very effective way to highlight the objectivity of academic writing. Scientific studies are conducted to explore the regularity of objective things in the world, so the focus is on the descriptions and analysis of objective things or phenomenon rather than the evaluations of subjective 
behaviors. Therefore, the academic written texts put emphasis on the objectivity of the statements which is an important feature of academic genre. For example,

(1) The hero spoke wonderfully so the audience applauded for a long time.

(2) The hero's wonderful speech resulted in lengthy applause from the audience.

In this example, with nominalization, the original process embodied by verbal groups "spoke" and "applaud" is transferred to a process embodied by nominal groups "speech" and "applause". During this transference, the sayer and the source of the action in the original process are omitted, which reduces the interpersonal meanings and increases the objectivity of the text.

Another device to construe the objective meaning in academic writing is the employment of modality metaphor. For example:

(3) The government should support the development of renewable energy.

(4) It's the government's responsibility to support the development of renewable energy.

In sentence (3), the use of modal operator "should" emphasizes the subjective tone of evaluation. From the perspective of individual's subjective point of view, this evaluation is not open for further discussions. In sentence (4), through the use of modality metaphor, the modal verb "should" in sentence (3) is replaced by the nominal clause "it's the government's responsibility", which weakens the subjective tone of the evaluation by construing the meaning as a fact rather than an opinion. In academic written discourse, modality metaphorical use of language enables writers to have great control of resources for construing evaluative meanings in an objective way.

Finally, the employment of norminalization in ideational metaphor makes written texts more accurate and concise which is in consistent with the academic register. For example, "in view of the fact that" VS. "seeing that", "what they have investigated" VS. "their investigation". Obviously, the use of nominalization is effective to condense meanings into words or phrases, which reduces the number of clauses and word markers that express logical relations.

\section{Implications for English Academic Writing Instruction}

Grammatical metaphor, especially nominalization, is a typical feature of academic written discourse. Knowledge about how to appropriately use grammatical metaphor places a crucial role in developing EFL learners' academic writing competence. In academic writing instruction, teachers should help students raise their awareness of register variations. For example, students need to understand different communicative purposes and the logical relationships among different parts of academic papers from other those of informal texts. More exposure activities should be included through detailed analysis of mentor texts to enable students to gain deeper insights into the field, tenor and mode in academic register. And through further discussions, students are expected to comprehend more about the basic styles and features of academic language. Both the content aspect and the language forms should be integrated in the discussion to foster students' abilities of establishing the connections between functions and forms of academic writing. Examples of sophisticated language use typical of academic texts created by nominalization should be explicitly implemented in the class. The multiple roles of nominalization in creating academic tones and cohesive discourses should be explained through comparison and contrast. Furthermore, the use of grammatical metaphors in academic writing to present evaluations in an objective and authoritative way can be further elaborated and practiced. Additionally, students should be encouraged to use nominal groups and grammatical metaphors to create meanings in writing research papers. Knowledge on nominal groups derivate from other lexicogrammatical forms, such as verbs, adjectives, clauses should be instructed in class, and students' abilities to transfer from congruent use of language to metaphorical use of language should be practiced. In terms of feedback on students' academic writing, in addition to the evaluations related to the logic and organizations of content, teachers also need to give corrective suggestions about the inappropriate language forms, which may help graduate students expand vocabulary and promote their development of overall language proficiency at an advanced level.

\section{Conclusion}

Grammatical metaphor is an important resource for constructing meanings in academic written texts. Ideational metaphor effectively condenses the complex information by increasing lexical density in the process of nominalization. Thus, more content information can be conveyed to readers with simple-structured clauses, which makes the text more formal. Nominalization also helps to establish the logic of theme-and-rheme in texts to organize the ideas in a cohesive and coherent way. In addition to the function of nominalization, the use of 
interpersonal metaphors, especially modality metaphors, presents the evaluations in a factual and objective tone in academic texts. Through grammatical metaphors, the conciseness of the academic papers has also improved. Therefore, in academic writing instruction, raising learners' awareness of employing grammatical metaphors reasonably, which is one of the basic requirements of academic register, may effectively improve learners' academic writing competence. Further research may focus on exploring the relationship between the application of grammatical metaphor and the development of learners' academic writing competence.

\section{Acknowledgments}

This research was financially supported by "the Fundamental Research Funds for the Central Universities+2015MS68".

\section{References}

Burns, A. (2001). Analysing Spoken Discourse: Implications for TESOL. In A. Burns \& C. Coffin (Eds.), Analysing English in a Global Context (pp.123-148). London: Routledge.

Chen, Y. P., \& Foley, J. A. (2004). Problems with the metaphorical reconstrual of meaning in Chinese EFL learners' expositions. In L. Ravelli \& R. A. Ellis (Eds.), Analysing academic writing: Contextualized frameworks (pp. 190-232). London: Continuum.

Christie, F. (2002). The development of abstraction in adolescence in subject English. In M. J. Schleppegrell \& M. C. Colombi (Eds.), Developing advanced literacy in first and second languages: Meaning with power (pp. 45-66). Mahwah, NJ: Lawrence Erlbaum.

Christie, F., \& Derewianka, B. (2008). School discourse: Learning to write across the years of schooling. London: Continuum.

Derewianka, B. (2003). Grammatical metaphor in the transition to adolescence. In A. M. Simon-Vandenbergen, M. Taverniers, \& L. Ravelli (Eds.), Grammatical metaphor: Views from systemic functional linguistics (pp. 185-220). Philadelphia/Amsterdam: John Benjamins. https://doi.org/10.1075/cilt.236.11der

Durst, R. K. (1984). The development of analytic writing. In A. N. Applebee (Ed.), Contexts for learning to write (pp. 79-102). Norwood, NJ: Ablex.

Halliday, M. A. K. (1978). Language as a Social Semiotic. London: Edward Arnold.

Halliday, M. A. K. (1985). Introduction to Functional Grammar. London: Hodder Arnold.

Halliday, M. A. K. (1993). Toward a Language-based Theory of Learning. Linguistics and Education, 2, 93-116. https://doi.org/10.1016/0898-5898(93)90026-7

Halliday, M. A. K., \& Matthiessen, C. M. I. M. (1999). Construing experience through meaning: A language-based approach to cognition. London/New York: Cassell.

Halliday, M. A. K., \& Matthiessen, C. M. I. M. (2004). An Introduction to Functional Grammar. London: Hodder Arnold.

Halliday, M. A. K., \& Martin, J. R. (1993). Writing Science: Literacy and Discursive Power. London: Falmer Press.

Liardet, C. L. (2013). An exploration of Chinese EFL learners' deployment of grammatical metaphor: learning to make academically valued meanings. Journal of Second Language Writing, 22, 161-178. https://doi.org/10.1016/j.jslw.2013.03.008

Liardet, C. L. (2015). Academic literacy and grammatical metaphor: mapping development. International TESOL Journal, 10(1), 29-46.

Martin, J. R. (1993). Life as a noun: arresting the universe in science and humanities. In M. A. K. Halliday \& J. R. Martin (Eds.), Writing science: Literacy and discursive power (pp. 221-267). London: The Falmer Press.

Ravelli, L. (2003). Renewal of Connection: Integrating Theory and practice in an understanding of grammatical metaphor. In A. M. Simon-Vandenbergen, M. Taverniers, \& L. Ravelli (Eds.), Grammatical Metaphor: Views from Systemic Functional Linguistics (pp. 37- 64). Amsterdam/Philadephia: John Benjamins.

Schleppegrell, M. J. (2004). Technical writing in a second language: the role of grammatical metaphor. In L. J. Ravelli \& R. A. Ellis (Eds.), Analysing academic writing: Contextualized frameworks (pp.172-189). New York: Continuum. 


\section{Copyrights}

Copyright for this article is retained by the author, with first publication rights granted to the journal.

This is an open-access article distributed under the terms and conditions of the Creative Commons Attribution license (http://creativecommons.org/licenses/by/4.0/). 